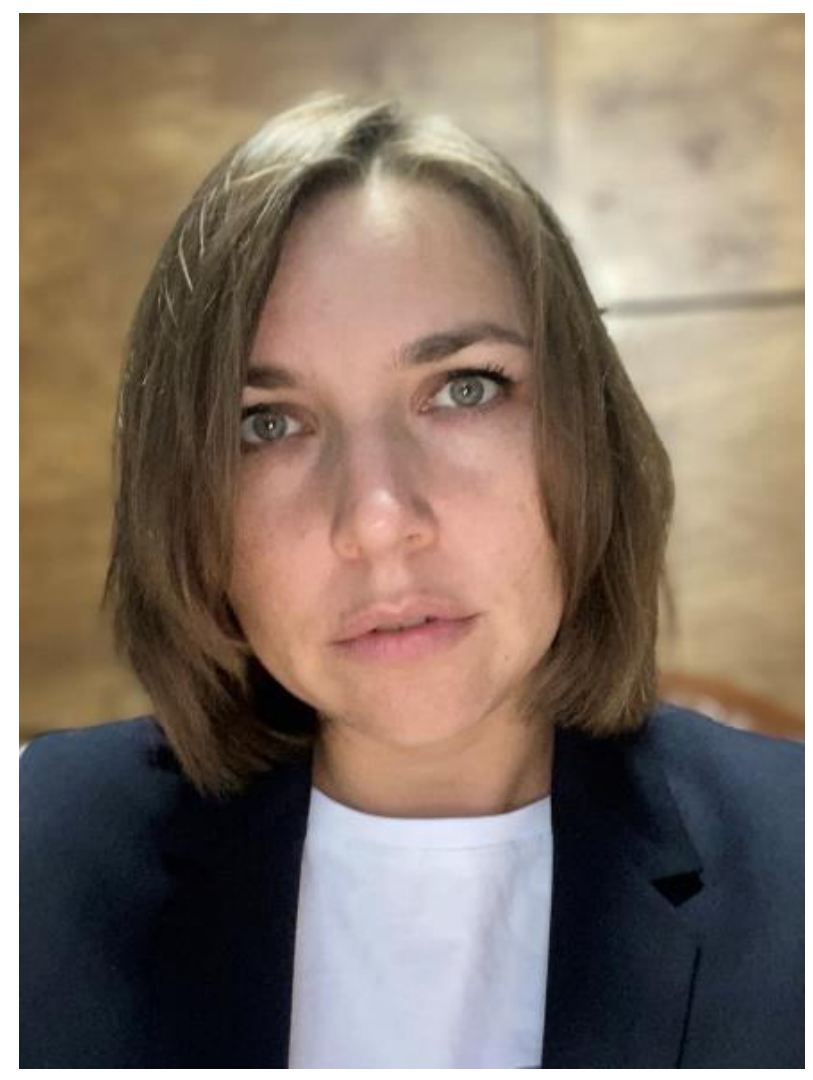

\author{
MAZNA \\ Olena, \\ graduate student of NSAL NAAS \\ olena.mazna@gmail.com
}

(Kyiv)

\title{
FRUITFUL WAY OF THE SCHOLAR, AGRARIAN, ECONOMIST, PROFESSOR KYRYL GEORGE TELESHEK (1894-1977)
}

The article is aimed to disclose main aspects of life, scholar and pedagogical activities of Kyryl George Teleshek, Doctor of Economics, Professor, Associate Member of Ukrainian Academy Of Agricultural Science (UAAS), "Honored Scientist of the USSR». Apparently in domestic historiography there are no detailed biographical insights as well as analytical notes of his scientific achievements on the problems of economy and organization in agricultural industries in the USSR. The methodology laid out in this publication uses general scientific and history specific ways, including analysis, synthesis and classification. There are also problemchronological, comparative-historical and personalization methods as well as historiographical and source analysis used in this paper.

There are main milestones of Teleshek's scholar life are highlighted. In particular, his higher education, formed scientific interests as well as overall his research directions. Beginning his scientific path he started at the Kharkiv Institute of National Economy, when in the 1930s joined the scientific expeditions to Kazakhstan, the Lower Dnieper Sands region, Donetsk and Zaporizhia regions. Lately in different periods he made his main achievements with the teams of the Institute of Agricultural Economics UAAS, Tsyurupynsky Research Station, Kharkiv Zootechnical Institute, 
V.V. Dokuchaev Kharkiv Agricultural Institute honored by the Labor Red Flag Order.

Having studied Kyryl Teleshek papers we can divide them into the following areas: agricultural production specialization; state and collective farms production profitability; streamlining of livestock production; scientific of labor arrangement; labor technical rationing. Analyzing Professor Kyryl Teleshek scientific achievements proved their importance to the development of agriculture and its scientific boost during in the period.

Key words: creative heritage, agriculture, economy, research institute, scientific achievements.

\section{ТВОРЧИЙ ШЛЯХ ВЧЕНОГО-АГРАРІЯ, ЕКОНОМІСТА, ПРОФЕСОРА КИРИЛА ГЕОРГІЙОВИЧА ТЕЛЕШЕКА (1894-1977)}

Статтю присвячено розкриттю основних аспектів життєвого шляху та науково-педагогічної діяльності доктора економічних наук, професора, членакореспондента УАСГН, «Заслуженого діяча науки УРСР» Кирила Георгійовича Телешека. Встановлено, що у вітчизняній історіографії відсутні як спеціальні біографічні дослідження, так $і$ вивчення й аналіз наукового доробку вченого з проблем економіки та організації сільськогосподарського виробництва в УРСР. Методологічним підгрунттям даної публікації $\epsilon$ загальнонаукові та спеціально-історичні методи, зокрема аналізу, синтезу та класифікаиії. Також застосовано проблемно-хронологічний, порівняльно-історичний методи та методи персоналізачії, історіографічного та джерелознавчого аналізу.

Висвітлено основні віхи творчого життя К.Г. Телешека, зокрема здобуття вищої освіти, становлення наукових інтересів та основні напрями його дослідницьких пошуків. Наукове сходження вчений розпочав $в$ Харківському інституті народного господарства, долучився до участі в організованих у 1930-х рр. наукових експедиціях до Казахстану, району Нижньодніпровських пісків, Донбасу та Запорізького району. Надалі в різні періоди основні свої напраџювання зробив у колективах УНДІ економіки сільського господарства ВУАСГН, Цюрупинської дослідницької станиії, Харківського зоотехнічного інституту, Харківського ордена Трудового червоного прапора сільськогосподарського інституту ім. В.В. Докучаєва.

Вивчення опублікованих праџь професора К.Г. Телешека дозволило їх умовно розділити за наступними напрямами: спеціалізація сільськогосподарського виробництва; підвищення рентабельності виробництва в радгоспах та колгоспах; організація виробництвва продуктів тваринництва; наукова організачія прачі; технічне нормування прачі. Аналіз наукових напрачювань професора К.Г. Телешека засвідчив їх значущість для розвитку сільського господарства та його наукового забезпечення у досліджуваний nepiod.

Ключові слова: творча спадщина, сільське господарство, економіка, науково-дослідний інститут, наукові напраџювання. 
The becoming of Ukrainian state is largely based on the historical heritage of our people, including scientific attainments, achievements of national scientists in different periods of the country. The task of historians of science is to rethink the scientific heritage, recreate forgotten and less-known men, add them to the glory pantheon of the prominent Ukrainians, and generally to create an authentic national history of Ukraine. In this regard, the study of the fruitful heritage of Doctor of Economics, Professor, Associate Member of the Ukrainian Academy of Agricultural Sciences (UACGN) (now - National Academy of Agrarian Sciences of Ukraine (NAAS)), 'Honored Scientist of the USSR' Kyryl George Teleshek [1, p. 269-270] seems relevant. Significant scientific achievements of the scientist in economics and agricultural production arrangement of the USSR in the middle of the last century contributed greatly to the development of agricultural science. However, in the scientific literature there are only few short biographical posts [2, p. 34-35] and some sporadic references of his scientific and pedagogical activity [3]. This paper aims to highlight the scientist lifetime, his foremost scientific, pedagogical and organizational activity aspects.

Kyryl Teleshek was born on March 18, 1894 in Kozelshchyna village, NovoSanzharsky district of Poltava province. Teleshek's poor peasant family of 12 people having only 1.5 acres of land joined the agricultural cooperative in 1922 [4]. After graduation from a rural school (1904-1908), he entered Poltava Medical School (1908-1911). Then he worked as a paramedic at zemstvo hospitals of Konstantinograd district of Poltava province. During 1915 to 1917 period he served as a paramedic of the vanguard banding detachment on the Southwestern War Front. At the end of 1917 he entered the preparatory courses of the Kyiv People's University, and in 1919 he became a Red Army soldier, a doctor assistant at the 4th Military Hospital. During 1920-1924 period, Kyryl Teleshek participated in the Kozelshche agricultural cooperative and worked for public organizations such as: Committees of Poor Peasants of Novo-Tagamlyk, land and sow panel and agricultural cooperative. 
In 1924 Poor Peasants Poltava Provincial Committee directed Teleshek to the Kharkiv Institute of National Economy (KINE). Under the leadership of the rector, Professor P.I. Fomin, this higher economic educational establishment carried both educational and research activities. The research department comprised of 32 researchers worked in specific areas such as: «World Economy», «National Economy of Ukraine during the war and revolution», «Agricultural Economics», «Theoretical Statistics», «Problems of moneyless circulation and inventory in accounting», etc. [5]. Moreover, the Institute cooperated with all research departments of the Ukrainian Academy of Sciences (UAS), namely the Department of World Economy and the Department of International Law. There were also study premises for Donetsk basin.

In 1928 he accomplished his studies at the Faculty of Economics and was qualified as an economist «with a bias in the trade cycle of foreign relations». After that, he as a graduate student entered the Department of Applied Economics, then had worked there as an assistant and later as an associate professor till 1932. In 1931 he published his first paper named «Balance of labor in agriculture («Horticulture» section)», and also participated in reporting the expedition results of the USSR Fruit and Berry Research Institute («Prospects of fruit growing in Kazakhstan»).

Starting as a part-timer in 1930, Kyryl Teleshek continued working in 1932 as a senior researcher at the Ukrainian Research Institute (URI) of Agricultural Economics of the All-Ukrainian Academy of Agricultural Sciences (UAAS) (Kharkiv) (until 1936) [4, p. 8]. The Ukrainian Research Institute of Agricultural Economics, created in 1928 for scientific service of the People's Commissariat of Land of the USSR, carried out agricultural production consulting for current scientific, state, cooperative and public issues of [6, p. 281]. The institution studied the agriculture productive forces, the socio-economic relation arrangements, elaborated production types of the industry functioning and its further development.

During this period, the scientist participated in four comprehensive scientific expeditions, namely: a) to Kazakhstan, to study the prospects for the development of fruit growing (1931); b) to the areas of the Lower Dnieper sands, to develop a plan 
for their mastering (1932); c) to Donetsk basin, to design a scheme for fruit and vegetable growing and study the suburban areas (1933); d) to the Zaporizhia region to prepare a plan for agriculture development with the electrification (1935). Using the research results from expeditions, he developed scientifically sound projects, which were approved by the State Plan and the Ministry of Agriculture of the USSR. The following works were documented in: «Fruit and Vegetable Farming of the Kharkiv Suburban Zone in the Second Five-Year Plan», 1932, «Lower Dnieper Sands for Service», 1934, «Upcoming Tasks of Fruit and Berry Production in the USSR», 1934, etc.

For 1936-1938 period Kyryl Teleshek has worked at the Tsyurupynsky Research Station (Kherson Region) as a Deputy Director for Research. The main tasks of the station were to research and implement the most profitable economic reclaiming of the Lower Dnieper sand massifs by growing forest, agricultural and industrial crops. Under his scientific leadership there was a master plan for the reclaiming of 200,000 hectares of Lower Dnieper sands developed. Being the scientific head of the station, he put sands reclaiming measures into practical implementation. The sand problem was at concern of many other scientists, including G. Borovikov, V. Rotmistrov and L. Savchenko who studied it and focused mainly on natural conditions. Kyryl Teleshek concentrated on a methodology how efficiently develop the sand massifs which then resulted in his doctoral dissertation namely «A plan of agricultural reclaiming of the Lower Dnieper sands» [4, p. 26]. This work was widely presented at the All-Union Agricultural Exhibition in 1940, and its author was awarded the Grand Silver Medal.

The Lenin All-Union Academy of Agricultural Sciences (UAAS) highly appreciated this work and recommended it to the State Plan of the Ukrainian SSR as a model for a comprehensive solution to the problem of land economic development. The main recommendations were about vegetable and fruit growing, because the production intensification in these areas eventually pipelined raw materials for canneries in the region. Recommendations set out in Kyryl Teleshek dissertation were implemented to the farms in the Kherson region. Following the successful 
defense of the dissertation in 1940, the scientist, the first among Ukrainian agrarian economists, was awarded the degree of Doctor of Economics by the decision of the Higher Attestation Panel of the USSR Ministry of Education on February 13, 1943. Kyryl Teleshek was awarded the academic title of Professor in 1946 by the Department of «Organization of Socialist Agricultural Enterprises».

During 1939-1941 Kyryl Teleshek worked as a senior researcher, head of the economics department of the Ukrainian Research Institute of Socialist Agriculture. During the evacuation from October 1941 to September 1943 he worked as a senior agronomist at the Ivanovo machine and tractor station (MTS), Saratov region. Upon returning, to, he joined the scientific part of the Ukrainian Research Institute of Socialist Agriculture (Kharkiv) as a head of the economics department and a deputy director. There he conducted an extensive economic research focused on the main issues of postwar agriculture in the USSR [7, p. 79]. The work «The question of use of the USSR collective farm productive forces in the postwar period» was published in 1945.

During 1943-1960, Kyryl Teleshek worked as a head of the Department of Economics and Arrangement of Agricultural Production at the Kharkiv Zootechnical Institute (nowadays - Kharkiv State Zooveterinary Academy). Since 1945 he became an acting deputy director for scientific and educational work and worked at the above-mentioned institution till 1957. During this period he published a number of works with the research results of the economic usage of the Lower Dnieper sands («The problem of agricultural development of the Lower Dnieper sands», 1948, «Agricultural reclaiming of the Lower Dnieper sands», 1952), increasing the livestock profitability ( «Economic premises for improving breeds of productive farm animals», 1956, «Resources to increase meat production in Ukraine», 1958, «Meat potential of cattle and its usage in the Ukrainian SSR», 1958), etc.

In 1959 he was elected the UAAS associate member of at the Department of Economics and Organization of Agricultural Production [8]. It should be noted that UAAS, (former UAAS (1935)) resumed in 1956, saw first elections of full members academicians and associate members two years later [9]. The management center 
running on a democratic basis proved its success, namely in the area of scientific and methodological coordination of UAAS network scientific institutions, agricultural universities and some specialized institutes subordinated to the Lenin All-Union Academy of Agricultural Sciences. A Research Coordination Council under the leadership of Doctor of Agricultural Sciences P.O. Gorshkov with the coordination panels on specific problems, subordinated to the respective Branch, coordinated the elaboration of problems common to several Branches and the forming of general academic reports, problem-oriented plans, as well as implementation plans, etc.

In total, there were 66 coordination panels, such as: 35 units - by the Branches, coordinate 4 problem-oriented units at the Department of Economics and Organization of Agricultural Production; 31 units - by research institutes of UAAS [9]. The coordination panels were led by academicians and associate members of UAAS. Professor Kyryl Teleshek led the coordination panels concerning the problem of «Improvement of the system of planning, accounting and reporting in collective and state farms» $[11$, p. 75], held special coordination meetings on a number of important related problems where both theoretic and empiric scientists participated. During them, there were the results of the conducted researches, work plans and questions for sharing and coordination of problem subjects among separate research units presented. Moreover, there were the results of the research method approbations, generalized best practices concerning specific problems as well as production implementation propositions proposals for implementation in production, etc. considered.

Under the leadership of Professor Kyryl Teleshek employees of the Department of Economics and Organization of Agricultural Production UAAS, Kharkiv Agricultural Institute and farm specialists have developed a new costs and revenues accounting system. In 1959 the system was put into practice at 3,000 farms, and then, following an effectiveness feedback, in 1960 it was rolled out at every collective farm in Ukraine [12, p. 31]. The designed accounting system allowed not only to keep labor cost and production resource records for certain production items, but to determine the cost, profitability and management KPI. 
According to the of the competition results, Kyryl Teleshek was appointed as a deputy head of the Economics and Agricultural Enterprises Department at the Kharkiv Red Flag of Labor Order Agricultural Institute after V.V. Dokuchaev in March 1960, where he worked till his last days [4, p. 4]. After his appointment, the scientist managed to open the first among agricultural universities laboratory of economic research. In mid 1960s, the department attained the most significant achievements when elaborated and implemented long-term development plans for 80 Donetsk region state farms.

During this period, Kyryl Teleshek was appointed to be the chairman of the Academic Council of the Faculties of Economics and Land Management at the Kharkiv Institute of Agriculture, and a member of the Academic Councils at the Kharkiv State University and the Kharkiv Zooveterinary Institute. Professor Kyryl Teleshek conducted lectures on the following subjects: «Economics of Socialist Agriculture», «World Agriculture», "Arranging and planning of production in state and collective farms», «Technical rationing», etc. He paid much attention to made it easy or every student to master the fundamentals and forge practical skills. For example, he developed a training program based on exemplary industrial management of studied enterprises, assigned to the corresponding institute departments. Thanks to putting theoretical knowledge into practice, students worked out proposals concerning productivity increase, livestock production cost reduction and so forth.

In the early 1970s, scientific interests of Professor Kyryl Teleshek encompassed contemporary issues in the agriculture in the Ukrainian SSR. He put the stress to the specificity and methods when solving individual problems and stressed the importance of defining the potential of agricultural production. Taking into consideration economic experiences of units from other industries helped him to prove that there was an urgent need to have a sustainable potential during transition to advanced systems of agriculture and livestock. Kyryl Teleshek convinced that the irrigation and effective reclamation in the Dnieper left-bank regions will help expand a land fund for agricultural production and increase their fertility [13]. According to 
the scientist, he suggested to identify the agriculture potential in every region of the Ukrainian SSR, taking into account geographic and economic conditions, intraregional and intra-district division of labor, as well as rational allocation of agriculture following the administrative-territorial structure of the republic.

Professor Kyryl Teleshek believed one of the most important problems was developing and justifying the most efficient production types of agricultural enterprises with regard to the discrepancies in geographic and economic conditions. Discovering rational types of agricultural enterprises, as the scientist argued, will improve production planning, technical equipment, and implement efficient management systems, better use of fixed and working capital, reduce losses, and so on. He noted that among diverse agricultural enterprises which evolving and upgrading will survive only the most rational ones. Kyryl Teleshek drew attention to the unresolved problems with industrial development and population density, the organization of highly productive irrigated agriculture, management of agricultural production, usage of fixed and working capital, labor force and updated technical equipment of agriculture.

It is worth mentioning that Kyryl Teleshek always actively participated in public life, conducted theoretical and economic seminars of teaching staff, took a word at local economic conferences, actively promoted economic knowledge not only among professionals, but also among agricultural workers.

He wrote about 70 scientific works on current issues of economics and organization of agriculture, and guided more than 100 separate works. Being acquainted with a number of his published helped form them into several areas: a) specialization of agricultural production; b) increasing the productivity of state and collective farms; c) organization of livestock production; d) scientific organization of labor; e) technical rationing of labor.

The scientist has trained 60 candidates and 15 doctors of economics, including
V. Yaroshenko,
M. Pisin,
K. Trakhtomirova,
Y. Kornilov,
G. Gushchin,
M. Dobrovolsky,
V. Madadaev,
V. Yevtushenko,
I. Rossokha,
P. Semiusov, 
M. Bublik, M. Polyansky and others. He was an official opponent for more than 30 candidate and doctoral dissertations.

According to Resolution № 60 by Bureau of the Kharkiv Regional Committee of the Communist Party of Ukraine and the Executive Committee of the Regional Council of Workers' Deputies of February 17, 1964 in accordance with the 70th anniversary of the birth and 55th anniversary of scientific, pedagogical and social activities, «... for merits in agricultural science development and for training highly qualified specialists» [14] and by a decree of the Presidium of the Verkhovna Rada of the Ukrainian SSR Professor Kyryl Teleshek was awarded the honorary title of «Honored Scientist of the Ukrainian SSR». For outstanding scientific achievements, the scientist was also awarded two orders of the Red Flag Labor, the Order «The Badge of Honor» and the Grand Silver Medal of the USSR Exhibition of Economic Achievements.

He passed away on August 7, 1977.

The study of the scientific heritage of Doctor of Economics, Professor, Associate Member of UAAS, Kyryl Teleshek proved the diversity of his interests, scientific achievements and their practical implementation. The scientist poured considerable light on the issues of specialization of agricultural production, the study of the peculiarities of the economic environment in order to define or expand economic, technological and organizational relationships. His achievements in economics and organization of agricultural production in the mid of the twentieth century became a significant contribution to the development of agricultural science and industry in general and therefore deserve further comprehensive research, analysis and dissemination in the scientific literature.

\section{Сиисок використаних джерел та літератури}

1. Вергунов В.А., Щебетюк Н.Б. Історія Української академії сільськогосподарських наук (1956-1962) / УААН, ДНСГБ ; за заг. ред. проф. В.А. Вергунова. Київ : Аграрна наука, 2008. 304 с.

2. Календар знаменних і пам'ятних дат в історії сільськогосподарської дослідної справи України на 2019 рік / НААН, ННСГБ ; уклад. : В.А. Вергунов, 
Х.М. Дмитрієва, С.Д. Коваленко ; за наук. ред. В.А. Вергунова. Київ, 2018. $352 \mathrm{c}$.

3. Харківська державна зооветеринарна академія. Історія кафедри менеджменту, економіки та маркетингу. URL : https://hdzva.edu.ua/management/istoriya-kafedry/. (дата звернення 14.07.2020).

4. Архів Харківського національного аграрного університету ім. В.В. Докучаєва. Особова справа Телешека Кирила Георгійовича (25.03.1960-07.08.1977). 88 арк.

5. Михайличенко Д.Ю., Єрмаченко В.С., Сахно О.А. Нариси $з$ історії Харківського національного економічного університету : монографія / під заг. ред. В.С. Пономаренка. Харків : ВД «ІНЖЕК», 2005. 326 с.

6. Щебетюк Н.Б. Розвиток аграрної науки України наприкінці 20-х - у 30i pp. XX ст. : монографія / НААН, ННСГБ, Ін-т історії аграр. науки, освіти та техніки ; наук. ред. В. А. Вергунов. Кам'янець-Подільський : ТОВ «Друкарня «Рута»», 2017. $380 \mathrm{c}$.

7. Ученые Харькова к годовщине освобождения родного города. Краткий обзор работы учебных и научно- исследовательских институтов за годы Отечественной войны / ред. кол. : Б.Ф. Вашура [и др.]. Харьков, 1944. 88 с.

8. Українська академія сільськогосподарських наук (1956-1962рр.) : зб. документів i матеріалів / УААН, ДНСГБ; уклад.: В.А. Вергунов, Н.Б. Щебетюк, Б.К. Супіханов, О.Б. Бакуменко ; під заг. ред. М.В. Зубця, Ю.Ф. Мельника ; наук. ред. В.А. Вергунов. Київ, 2006. 380 с.

9. Вибори нових академіків і членів-кореспондентів Української академії сільськогосподарських наук. Вісник сільськогосподарської науки. 1959. № 8. C. 52-53.

10. Власюк П.А. Підсумки роботи УАСГН за 1959 р. і завдання науководослідних закладів на 1960 р. по здійсненню рішень Грудневого Пленуму ЦК КПРС і XXI з’їзду КП України. Вісник сільськогосподарської науки. 1960. № 4. C. 21.

11. Короткий звіт про наукову діяльність установ Української академії сільськогосподарських наук за 1960 р. Київ : вид-во УАСГН, 1961. 99 с.

12. Власюк П.А. Підсумки роботи науково-дослідних установ УАСГН за 1958 р. і завдання на 1959-1965 рр. Вісник сільськогосподарської науки. 1959. № 8. C. 18-43.

13. Постанова бюро Харківського обкому КП України i виконкому обласної Ради депутатів трудящих «Про присвоєння Телешеку К.Г. звання «Заслужений діяч науки УРСР»» № 60 від 17 лютого 1964 р. // Архів Харківського національного аграрного університету ім. В.В. Докучаєва, Особова справа Телешека Кирила Георгійовича (25.03.1960-07.08.1977), арк. 30.

14. Телешек К.Г. К вопросу об основных проблемах экономики сельского хозяйства Левобережной части Украины. Проблемы экономики сельского хозяйства / МСХ УССР, Харьков. Ордена Трудового Красного знамени с.-х. ин-т им. В.В. Докучаева. Харьков, 1970. Вып. 1. С. 3-5. 


\section{References}

1. Verhunov V.A., Shchebetiuk N.B. (2008). Istoriia Ukrainskoi akademii silskohospodarskykh nauk (1956-1962) [History of the Ukrainian Academy of Agricultural Sciences]. Kyiv : Ahrarna nauka. 304. [in Ukrainian].

2. (2018). Kalendar znamennykh i pam'iatnykh dat v istorii silskohospodarskoi doslidnoi spravy Ukrainy na 2019 rik. [Calendar of significant and memorable dates in the history of agricultural research in Ukraine for 2019 year]. Kyiv. 352. [in Ukrainian].

3. Kharkivska derzhavna zooveterynarna akademiia. Istoriia kafedry menedzhmentu, ekonomiky ta marketynhu. [Kharkiv State Zooveterinary Academy. History of the Department of Management, Economics and Marketing]. URL : https://hdzva.edu.ua/management/istoriya-kafedry/. (date of reference 14.07.2020). [in Ukrainian].

4. Arkhiv Kharkivskoho natsionalnoho agrarnoho universytetu im. V.V. Dokuchaieva [Archive of Kharkiv National Agrarian University named after V.V. Dokuchaeva]. Osobova sprava Telesheka Kyryla Heorhiiovycha [Personal file of Teleshek Kirill Georgievich]. (25.03.1960-07.08.1977). 88 p.

5. Mykhailychenko D.Yu., Yermachenko V.Ye., Sakhno O.A. (2005). Narysy $\mathrm{z}$ istorii Kharkivskoho natsionalnoho ekonomichnoho universytetu [Essays on the history of Kharkiv National Economic University]. Kharkiv : VD «INZhEK». 326p. [in Ukrainian].

6. Shchebetiuk N.B. (2017). Rozvytok ahrarnoi nauky Ukrainy naprykintsi 20$\mathrm{kh}-\mathrm{u}$ 30-i rr. KhKh st. [The development of agricultural science in Ukraine in the late 20's - 30's of the twentieth century]. Kamyianets-Podilskyi : TOV «Drukarnia «Ruta»». 380p. [in Ukrainian].

7. (1944) Uchenye Kharkova $\mathrm{k}$ godovshchyne osvobozhdenyia rodnoho goroda. Kratkyi obzor raboty uchebnykh y nauchno- yssledovatelskykh instytutov za gody Otechestvennoi voiny [Kharkov scientists on the anniversary of the liberation of their hometown. A brief overview of the work of educational and research institutes during the Patriotic War]. Kharkov. 88p. [in Ukrainian].

8. (2006). Ukrainska akademiia silskohospodarskykh nauk (1956-1962 rr.) : zb. dokumentiv i materialiv [Ukrainian Academy of Agricultural Sciences (19561962): coll. documents and materials]. Kyiv. 380p. [in Ukrainian].

9. (1959). Vybory novykh akademikiv i chleniv-korespondentiv Ukrainskoi akademii silskohospodarskykh nauk [Election of new academicians and corresponding members of the Ukrainian Academy of Agricultural Sciences]. Visnyk silskohospodarskoi nauky [Bulletin of Agricultural Science]. № 8. 52-53p. [in Ukrainian].

10. Vlasiuk P.A. (1960). Pidsumky roboty UASHN za 1959 r. i zavdannia naukovo-doslidnykh zakladiv na 1960 r. po zdiisnenniu rishen Hrudnevoho Plenumu TsK KPRS i KhKhI z'izdu KP Ukrainy [The results of the UAAS for 1959 and the tasks of research institutions for 1960 to implement the decisions of the December Plenum of the Central Committee of the CPSU and the XXI Congress of the CP of 
Ukraine]. Visnyk silskohospodarskoi nauky. [Bulletin of Agricultural Science]. № 4. 21. [in Ukrainian].

11. (1961). Korotkyi zvit pro naukovu diialnist ustanov Ukrainskoi akademii silskohospodarskykh nauk za $1960 \mathrm{r}$. [A brief report on the scientific activity of the institutions of the Ukrainian Academy of Agricultural Sciences for 1960 year]. Kyiv : vyd-vo UASHN. 99. [in Ukrainian].

12. Vlasiuk P.A. (1959). Pidsumky roboty naukovo-doslidnykh ustanov UASHN za 1958 r. i zavdannia na 1959-1965 rr. [The results of the work of research institutions UAAS for 1958 and the tasks for 1959-1965]. Visnyk silskohospodarskoi nauky [Bulletin of Agricultural Science]. № 8. 18-43. [in Ukrainian].

13. Postanova biuro Kharkivskoho obkomu KP Ukrainy i vykonkomu oblasnoi Rady deputativ trudiashchykh «Pro prysvoiennia Telesheku K.H. zvannia «Zasluzhenyi diiach nauky URSR»» № 60 vid 17 liutoho 1964 r. [Resolution of the Bureau of the Kharkiv Regional Committee of the Communist Party of Ukraine and the Executive Committee of the Regional Council of Workers' Deputies "On the assignment of Teleshek KG title «Honored Scientist of the USSR» № 60 of February 17, 1964.] // Arkhiv Kharkivskoho natsionalnoho ahrarnoho universytetu im. V.V. Dokuchaieva, Osobova sprava Telesheka Kyryla Heorhiiovycha [Archive of Kharkiv National Agrarian University named after V.V. Dokuchaeva, Personal file of Teleshek Kirill Georgievich]. (25.03.1960-07.08.1977), ark. 30.

14. Teleshek K.G. (1970). K voprosu ob osnovnykh problemakh ekonomyky selskoho khoziaistva Levoberezhnoi chasty Ukrainy [On the question of the main problems of the agricultural economy of the Left Bank of Ukraine]. Problemy ekonomyky selskoho khoziaistva [Problems of agricultural economics]. Kharkov. Issue. 1. 3-5. [in Ukrainian].

\section{Рецензент:}

Гутник М. В., к.і.н., доцент

Радогуз С. А., к.і.н. 